\title{
Adelino Magalhães: herdeiro de Festa $^{l}$
}

Resumo: Este artigo visa apresentar Adelino Magalhães como autor legatário dos preceitos estéticos propostos pela Revista modernista Festa. Para isso, são estudados brevemente os textos publicados no mensário pelo autor e as obras que pertencem à década de XX: Casos e Impressões; Visões, cenas e perfis; Tumulto da vida; Inquietude e A hora veloz.

Palavras-chave: Adelino Magalhães; revista Festa; Modernismo

\begin{abstract}
The present article aims to introduce Adelino Magalhães as an author who inherited the aesthetic precepts proposed by the modernist magazine Festa. In order to do so, we have briefly studied the texts published in the periodical, as well as the following works from the 1920's: Casos $e$ Impressões; Visões, cenas e perfis; Tumulto da vida; Inquietude, and A hora veloz.
\end{abstract}

Keywords: Adelino Magalhães; Festa Magazine; Modernism

\section{A multidão de Adelino Magalhães em Festa}

A revista Festa circulou, sobretudo no Rio de Janeiro, entre 1927 e 1929 . Imbuída da crença da construção do nacional a partir do universalismo e do totalismo, Festa exaltou uma visão de arte ligada ao Espírito, edificando assim uma estética que interpretou o mundo pósguerra como aquele que havia fracassado, que não merecia mais crédito, pois era voltada ao materialismo. Afirma Hauser (HAUSER, 1998, p. 958) que o século XX começa depois da Primeira Guerra Mundial. Seus impactos foram sentidos por todo o mundo, e a mutação, ocorrida no período posterior a 1914, levou a um discurso fragmentado, a um sentimento de desilusão, a uma crença no espírito, já que o humano não era digno de confiança, e era necessário buscar uma forma de superar o cataclismo da modernidade. A atmosfera de desespero levou o homem a buscar, no passado, na memória, elementos para alimentar a mente e o espírito.

A arte espiritualista ou totalista, proposta por Festa, não desejava estar presa a antigos modelos, mas compreendia que não havia como criar novos caminhos sem considerar

\footnotetext{
${ }^{1}$ Este artigo é um recorte da dissertação defendida, na UFRGS, em dezembro de 2005, denominada Revista Festa e a modernidade universalista na arte. Um estudo de caso: Adelino Magalhães.

* Joseane Rücker é doutoranda em Letras pela UFRGS.
} 
os antigos, já que os menosprezar seria negar tudo que até então teria sido assimilado e compreendido. Para inovar, era necessário conhecer as antigas propostas, por isso insistia em dialogar com a tradição. Membro ativo do mensário, Adelino Magalhães é um dos autores que melhor realiza o projeto estético do periódico.

Quem sempre viveu na cidade e, portanto, em meio à modernização, torna-se incapaz de compreender as modificações abruptas ocorridas no processo de mecanização na década de 20 no Brasil ou, se quisermos estender um pouco mais os nossos horizontes, na Europa do século XIX, ou seja, na Londres de Edgar Poe e na Paris de Charles Baudelaire. Acostumados a conviver com a multidão e com a velocidade do mundo moderno, nada mais nos assusta; no entanto, nem sempre foi assim, já que, pelo menos para os participantes do mensário carioca, tal transformação provocava temor e ânsia.

A arte, para os colaboradores de Festa, mostrava-se ameaçada pelo materialismo e pelo cientificismo que acompanhavam o processo da modernidade. Nadando contra a corrente - porque não exaltava a assimilação imediata das vanguardas, já que desconfiava de sua produtividade e de suas origens -, o grupo de Festa via a atualidade, a hora veloz, como denominara Adelino Magalhães, como um período de tumulto em todas as instâncias, uma oportunidade para reavaliar a hodierna situação, repensando e reorganizando os impactos do passado, como, por exemplo, a guerra. Essa reavaliação fez com que o grupo criasse uma estética que objetivasse o voltar-se para si como um processo de reflexão maduro em retaliação ao cientificismo e ao materialismo que surgiam no pós-guerra.

De acordo com Mário Camarinha (CAMARINHA, 1978, p. 18), Adelino Magalhães é o maior nome de Festa, embora já tivesse participado do grupo a partir do mensário América Latina (1918) com o texto "Dedeco, discípulo de Tranquilino", publicado em Tumulto da vida. Legatário de uma estética que utiliza elementos do subconsciente, mostrando-se sucessor da estética simbolista, os companheiros do mensário (supostamente MURYCY, 1928, p. 23) afirmam em texto publicado em Festa, de junho de 1928, que sua arte, de caráter supra ou infra-realista, não fora importada como a dos participantes do movimento PauBrasil, o que pontuaria o ineditismo da estética do autor. Logo, Adelino é vislumbrando também como um precursor do supra-realismo, hoje denominado surrealismo.

Em novembro de 1927, Adelino publica em Festa o texto "Já vai Dedeco para os seus quarenta" e, em junho de 1928, "Dedeco, discípulo de Tranquilino". Dedeco, discípulo de feições amarfanhadas, surdo de um ouvido e falando com dificuldade, é amado pelo filósofo Tranquilino, mas pouco sabemos nesse conto da filosofia do último. No texto, o narrador inicia afirmando que a vida de Dedeco não inspiraria interesse a certos homens frívolos, pois 
era pacata, sem grandes ações ou aventuras, já que seu interesse era desvendar os enigmas do Destino. Não há como chamar a atenção de outrem sem apresentar uma vida "que é frívola e brutalmente sequiosa de sangue e dos sensuais estertores das grandes misérias de uns, que são ao mesmo tempo o pedestal da glória d'outros" (MAGALHÃES, 1928, p. 11). Dedeco compreende que o sucesso e a derrota fazem parte dos movimentos humanos, mas com qual finalidade? Já que estávamos presos a um estranho gozo de dor, devíamos prender a nossa atenção ao Espírito em uma fidalguia insuperável e eterna. A procura pela espiritualização em Adelino pode ser entendida como uma reação às rupturas promovidas pelo mundo moderno (aquele frívolo e egoísta), uma compensação para aqueles que almejam "levar a humanidade ao divino dos seus destinos".

De sorriso triste "tal uma gota d'água caída do salgueiro sobre a sepultura" (MAGALHÃES, 1928, P. 11), Dedeco agarra-se ao passado de tal forma que só relê o que já leu para poder sentir mais profundamente; e, selvagemente conservador, vai-se acorcundando para o passado. Dessa forma, Dedeco decide-se, na arquitetura de seu ideário, dar apenas "umas pinturazinhas de quando em vez" no edifício de suas opiniões. Dedeco compreende que as idéias precisam de amadurecimento, logo de tempo para melhor serem assimiladas, e por esta razão amaldiçoa os tempos presentes e:

vai-se acorcundando para o passado, com mais inteligentes e simpáticos olhos sobre outrora, porque os leva cheios do desconforto de tudo que não seja esse passado tumultuoso e férico de ilusões! Selvagemente conservador - e o passado de mocidade ele o conserva como a recordação de uma encantada paisagem jamais tornada a ver e diante da qual todas as outras são de uma absurda, de uma incompreensível e blasfema inferioridade! (MAGALHÂES, 1928, p. 11)

Assim, tal qual para Dedeco, a arte, para o grupo do Mensário, deve ter um projeto estético bem-delineado, ainda que se possa fazer parte do processo criativo acrescentar novos preceitos; todavia, é importante ressaltar que já ter definido uma estética é, sem dúvida, não assimilar facilmente os preceitos vanguardistas como fizeram os paulistas de 1922, conforme acreditam os colaboradores de Festa.

O filósofo de Adelino Magalhães procura por sua essência, está perdido em meio à modernidade, e afirma o narrador "Não ama a cidade, Dedeco!... Se na ausência dela, sente algo de vazio, é pelo hábito do tumulto inconsistente!...” (MAGALHÃES, 1928, p. 11). A multidão cria no filósofo uma experiência próxima à reflexão ensejada por Edgar Alan Poe em "O homem da multidão", ou seja, os indivíduos estão cercados por muitos, mas simultaneamente distantes de todos e de si mesmos, gerando um mal-estar insuportável que se denomina anonimato. Todos os olhares estão perdidos na multidão das grandes cidades. E, tal qual a personagem do conto de Poe, Dedeco também persegue a multidão "numa curiosidade 
lorpa", assim como no passado fizera Tranquilino que não crê na amizade, no outro, mas somente na solidão, pois deseja estar só, almeja afastar-se para religar-se a sua essência:

Só na solidão dos que pensam diferente dos outros: na solidão dos que sentem diferente dos outros; só, na solidão dos espontaneamente superiores; na solidão dos que são como um gesto de graça - tão nostálgico de si mesmo! - pairando sobre as brutais contingências da vida! (MAGALHÃES, 1928, p. 14)

Perdido, Dedeco não quer escravizar-se, não quer massificar-se e, a partir dessa atitude, ele torna-se incapaz de submeter-se a qualquer método, lendo do meio para o fim e do fim para o princípio as suas obras "num eterno pavor de se escravizar a quem quer que seja" (MAGALHÃES, 1928, p. 12). Com as cidades, as pessoas tornam-se uniformes, e Dedeco quer encontrar-se, quer tornar-se único; no entanto, nessa trajetória em busca do seu Destino, muitas vezes perde o caminho:

a procurar sempre as Alturas e tão atraído por elas, que levando a contemplá-las, de longe, esqueceu-o de galgar a banalidade dos primeiros degraus para atingi-las!...Depois, quando teve consciência do erro, era tarde! Tarde para galgar os começos da Altura - ele assim achou, no desânimo que lhe veio de 'ter perdido tanto tempo'! (MAGALHÃES, 1928, p. 12)

O filósofo das alturas está desorientado e intui que todo o esforço restar-se-á inútil. É incapaz de "acompanhar o turbilhão polifônico, duêndico, voraginoso do Século!" (MAGALHÃES, 1928, p. 13). Para suportar as agruras do excessivo trabalho mental, "o discípulo de Tranquillino põe-se a correr, a fazer caretas e a dizer imbecilidades!..." (MAGALHÃES, 1928, p. 13). É assim que ele consegue por fim "estabelecer o equilíbrio e evitar ao jovem-pensador dores de cabeça e insônia!...” (MAGALHÃES, 1928, p. 13), mas mesmo que voe e que vague, por vezes, de forma inconsciente, Dedeco sente-se mal "num país onde o pé dos foot-ballers ${ }^{2}$ tem mais valor do que o cérebro dos pensadores!" (MAGALHÃES, 1928, p. 14). Sonambulizado à luz do dia, Dedeco não acredita em verdades únicas - sobretudo quando elas provêm de outrem -, e percebe que no Rio de Janeiro:

há um enxame de mestiços farejadores das verdades mastigadas d'além-mar (e das mentiras, outrossim) - enxame este que sacode a cachola vazia, em reverências profundas, diante de um orador de sabor vieirense, que leva a desamassar em todos os sentidos banalidades quilométricas, que tendem a endeusar sua pessoazinha!... (MAGALHÃES, 1928, p. 14)

Tudo é perdoado sob a bandeira do progresso, e essa utopia forma-se, de acordo com Dedeco, a partir de uma balança que equilibraria, em seus dois pratos, espiritualismo e materialismo. No cerne desse movimento estaria o destino infindável de um dia alcançar o equilíbrio.

Envergonhado, irritado e medroso, Dedeco volta-se para si e se enfarrusca em atitude hostil, organizando uma relação com a vida, de acordo com o narrador, que a vê como um

\footnotetext{
${ }^{2}$ A crítica à supervalorização do futebol ressurge nos ensaios de Tasso da Silveira e Andrade Muricy.
} 
"pavoroso enigma do Destino". Em meio a tantas confusões, os olhos de Dedeco "se embaçam de uma rancorosa tristeza de insofrido viajante, que perdeu contudo o comboio..."(MAGALHÃES, 1928, p. 16). Esse comboio que remete à fugacidade será recorrente na obra do autor.

Em texto de novembro de 1927, em Festa, Adelino Magalhães (MAGALHÃES, 1927, p. 4) escreve “Já vai Dedeco para os seus quarenta...”. Assim, alguns anos mais tarde na vida do discípulo e filósofo, ele é analisado pelo narrador como aquele que "não se eleva, nem declina", pois tornara sua vida "cristalizada". Perdido de si mesmo, Dedeco, perto dos quarenta, sente "saudade de si próprio", pois se perdeu na jornada do autoconhecimento e foi consumido pelo mundo e por suas modernidades. Para o discípulo de Tranquilino: "Foram-se as esperanças, na melancólica morbidez: após, foi o frêmito das esperanças; enfim o eco derradeiro do derradeiro frêmito. O desencanto da terra...” (MAGALHÃES, 1927, p. 4). Desiludido, Dedeco sabe que tudo é transitório e até mesmo na relação com as mulheres o que lhe resta é a fugacidade.

Referindo-se à massa, Dedeco proclama que "tem horror à massa, ao anonimato da massa, ao esparrame disciplinado da platéia..." (MAGALHÃES, 1927, p. 4). E, buscando descortinar a magia do universo, aos quarenta Dedeco: "lacrimeja, então, penalizado de si mesmo... Mas quando se recorda de que, no Universo, só ele dele assim se condói, com essa força de se condoer... um arrepio macabro lhe corre os nervos!" (MAGALHÃES, 1927, p. 4). E não suportando mais o seu frio mistério, Dedeco termina sublimando-se em busca de uma Consciência Universal.

Adelino Magalhães compactua com o ideário do Mensário, já que crê na festa interior, ou seja, na celebração do triunfo e do lampejo do homem para o divino no homem: única forma de superar o cataclismo da modernidade. Entregar-se à multidão, decorrente da modernidade, é vivenciar o choque, e a maneira encontrada por Dedeco para sobreviver a ele é expandir-se, transpassar-se, por isso há na personagem um misto de loucura, uma suprarealidade. É nesse universo intangível que nos deparamos com o efêmero como uma tentativa de construir o que no presente voeja. O grupo de Festa quer desvelar a modernidade e a sedução das cidades, mas não deseja inebriar-se dela, sobretudo se essa modernidade ou protótipo de civilização vier de fora como algo importado, que é o caso da assimilação acrítica das vanguardas. O movimento de envolver-se e de refugiar-se constitui um traço inerente ao artista moderno que ora se embrenha na multidão, e mistura-se a ela, ora a despreza, tornando-se só. 


\section{Casos e impressões da roça, da burguesia e da infância}

Para melhor avaliarmos a obra de Adelino Magalhães, estenderemos nossa análise para além dos textos publicados em Festa, incluindo os livros Casos e impressões (publicado em 1916 e republicado em 1926); Visões, cenas e perfis (publicado em 1918 e republicado em 1932); Tumulto da vida (publicado em 1920 e republicado em 1932); Inquietude (publicado em 1922 e republicado em 1932); A hora veloz (1926); Os violões (1927); Câmera (1928). É importante esclarecer que essas duas últimas obras são partes integrantes da edição de volume único de 1963, da José Aguilar, de Os momentos.

Nas primeiras páginas de Casos e Impressões, vislumbramos, nas discussões rotineiras do conto "As bananas", a crítica do autor aos sentimentos mesquinhos e, por vezes, materialistas do ser humano. No conto, o personagem João leva bananas de presente para o amigo Maneco e, em meio a esse gesto aparentemente sem importância, intrigas são instaladas entre os interlocutores, visto que, em verdade, João, ao mesmo tempo em que dá as bananas para o companheiro, o desafia, pois Maneco havia caçoado das frutas do companheiro que nasciam na encosta do morro, lugar desapropriado para plantá-las de acordo com o colega. Há nesse conto um ar de vingança, já que Maneco não acredita que João seria capaz de produzir bananas na encosta do morro. No final do texto, esse leva as bananas consigo com a ajuda do empregado:

O João é que se mostrava indeciso entre olhar para o colega e olhar para o molecote que viera
do curral, com o chapéu de palha desabado, a camisa imunda, as calças arregaçadas e em
trapos, a cara negra e lustrosa voltada para o chão. Por fim, pôs-se o João a olhar muito
seriamente para o empregado, enquanto o fazendeiro de fora saía em busca do cavalo, a
resmungar e a bater com as botas em cima das fezes de animais, espalhadas pelo terreiro.
(MAGALHÃES, 1963, p. 77)

Em "A vingança", conto do mesmo livro, o personagem Mané, roceiro, é casado com Sá Teresa, e ela, por sua vez, mantém um relacionamento amoroso com Chico Catinga. A vingança de Mané é fazer a mulher fumar os "pentelhos" do amante. Vingança calculada, já que Mané agüentara por muito tempo ter sido "cornudo". Aqui também o homem aparece como aquele capaz de calcular, meditar e pôr em prática sua represália. Sabemos que um dos projetos da Revista era abarcar o homem total, assim faz parte integrante do projeto estético de Adelino também representar o ser humano pleno, incluindo seus instintos, sobretudo aqueles de origem sexual. 
Essa representação do homem, a partir dos seus impulsos, pode ter chocado o público de 1916, mesmo que tal mistura de estilos ${ }^{3}$ tenha sido uma das características da época. Para as famílias bem-comportadas, Adelino era, sem dúvida, um pervertido, um imoral, no entanto esse tom natural da obra Casos e Impressões não é só uma herança de apenas um movimento estético, mas uma tentativa das diversas estéticas que confluíam no período ${ }^{4}$ de representar o homem em sua plenitude: corpo e espírito, e suas diversas facetas. Uma concepção semelhante aparecera muito antes na literatura, sobretudo européia, quando os românticos trazem o lado feio, grotesco e repugnante para as suas obras. Um exemplo pode ser vislumbrado no corcunda, de Nossa Senhora de Paris, de Victor Hugo. Entretanto, se o livro de Adelino inicia em tom mais naturalista ou expressionista, percebemos, entrecortando o texto, a presença de discussões de caráter metafísico. Observemos o tom de fatalidade recorrente no livro estudado - no trecho citado a seguir:

O aluarado silêncio, lá fora, se universalizava, extático, sonambúlico, monjamente místico, como se nele se houvesse paralisado toda a lírica e apavorada e crente alma do caboclo, tão só, tão tíbio frente à natureza augusta! E nesse silêncio, as vinganças, os ódios covardes fundiamse ao frio desvitalizado e macabro do luar, que parecia aplaudir, como monstruoso duende, num bater de palmas de mãos descarnadas, à fatalidade incolor das coisas... (MAGALHÃES, 1963, p. 79)

Ecoa, de sua obra, uma amargura fina. Assim, se, por um lado, achamos até engraçado ou irônico a atitude da personagem Mané, por outro compreendemos que existe uma angústia que abafa quaisquer outros sentimentos na alma do caboclo ${ }^{5}$ : "Vancê gozô! Vancê queria novo macho e ele veio uma purção de vêis, hein! E Mané, quando ele tava aí, em cima de vancê cobrindo vancê, sua égua... Mané tava lá, na enxada véia, trabaiando como um cativo...” (MAGALHÃES, 1963, p. 80). E, após o desgosto e a vingança saciada, um delicioso prazer instala-se na protagonista: "Era um gozo infinito, que passava de elegante sorriso e malicioso a uma gargalhada estridente, caveirenta” (MAGALHÃES, 1963, p. 79).

Em outros trechos, a animalização e o instinto tornam-se ainda mais evidentes, apresentando flagrantes escabrosos, grosseiros e até imprevistos:

\footnotetext{
${ }^{3}$ Augusto dos Anjos também faz uma fusão interessante dos preceitos científicos da época e do grotesco às aspirações de caráter metafísico e sublime como, por exemplo, em "Eterna mágoa" e "Uma noite no Cairo". Andrade Muricy (MURICY, Andrade. Panorama do Movimento Simbolista Brasileiro. Perspectiva: Rio de Janeiro, 1987; p. 873) aproxima o autor de Cruz e Sousa. Esta cisão do homem parece ser, inclusive, uma tendência de época.

${ }^{4}$ Era uma tendência comum no período a publicação de jornais de cunho erótico. Sonia Brayner afirma em $O$ Labirinto do Espaço Romanesco que autores consagrados, como Olavo Bilac, escreviam nesses periódicos marginais sob pseudônimos. O pseudônimo de Olavo Bilac era Bob.

${ }^{5}$ Lembremos que já em Adelino vislumbramos a representação do caboclo, logo anterior a Juca Mulato, de Menotti Del Picchia.
} 
Quá tocaia! Ele tá lá mais é bêbo, como um danado! Eu sube fazê a coisa: êle tava todo prosa, na venda do sô Coroné, e êle tava só falando de uma prução de valentia... que tinha brigado, em Minas... que quando tava em Santa Derfina tinha dado num turco... que êle non ia prêso pruquê os chefes gostava dêle... que êle matô um criolão dêsse tamanho, no Oeste e... e qu'inda foi cobri a muié do crioulo e as fia... e uma prução de coisa que non acabava mais! Os outro rindo por trás de Mané e Mané fingindo que não dava pela marotêra... Ah! véia, Mané sabia que tava com uns chifrão dessa grandura! (MAGALHÃES, 1963, p. 80).

Já no conto "As rezas", Zé Custódio é como um capataz de fazenda que obriga os negros a rezarem sucessivas vezes. Depois de muitas rezas, os homens mostram-se famintos. Naquele dia, o dono da fazenda havia prometido peru a todos, no entanto Zé Custódio sempre achava uma nova reza necessária antes do prometido banquete. Cansados e com fome, os negros miseráveis transformam-se em animais. Estabelece-se uma baderna. Um panorama alucinante é apresentado pelo autor; e assassinatos são cometidos entre a pancadaria geral. Como outra das fatalidades fotografadas por Adelino, os cachorros da casa acabam comendo o peru em meio à confusão. Sem dúvida, entrevíamos já nas primeiras páginas do autor a configuração da decadência e do reconhecimento do desnível econômico de nosso país. Observemos um trecho desta luta alucinante pela sobrevivência:

Os porretes já bailavam, produzindo estalos de secura, às vezes desmentidos por um deslizamento gorduroso...

Fios de sangue começaram a correr pelas cabeças e a pingar no chão; corpos baqueavam, e a luta se tornava cada vez mais acesa.

Ela havia principiado em torno do Zé Custódio, quase todos se havendo emblocado contra ele: mas alguns neutros, que foram apartar, apanharam, em franca colaboração com os 'decididos' do menor grupo, simpático ao negrão-chefe; e estes neutros, instintivamente, também se puseram a colaborar, reagindo, na pancadaria que jorrava dos homens do mandão (MAGALHÃES, 1963, p. 90).

Adelino compreendia que falar em modernidade nesse país não era uma tarefa simples. É fácil cobrir o subdesenvolvimento com o colorido e os gritos das vanguardas, difícil é desvendar a miséria e a hipocrisia da sociedade. Poucos eram os projetos que visavam pintar o Brasil como ele realmente era: fragmentado, multifacetado, pobre e analfabeto. É sabido que a modernidade fizera-se na década de 20, mas é importante salientar que ela não era para todos. Infelizmente, a concepção de subdesenvolvimento surgiria na Literatura Brasileira somente após a Revolução de 30, e é com os autores dessa década que a miséria será denunciada.

$\mathrm{O}$ descontentamento do autor em relação à realidade que se configura no início do século XX está delineado também no conto “A prisão da Candonga”. É importante salientar que os negros, mulatos, caboclos e roceiros de Adelino são personagens apresentados em meio à sua condição, em seu habitat natural, dependentes, muitas vezes, de senhores ou patrões, mas sobretudo de sua condição humana, ou seja, de seus medos, de seus desejos de vingança, de seus instintos etc. 
No conto "O subterrâneo (Cancioneiro de quatro confidências malditas)", da obra Inquietude, vislumbramos ainda um tom sensual à narrativa a partir da trajetória de uma mulher que se entrega aos instintos, em que é descrita como a "fera devorou a ave". O instinto é discutido por Adelino Magalhães como um sentimento que domina os homens e os dispersa de suas indagações metafísicas e religiosas, provocando o caos. Vejamos um trecho a seguir:

Ainda sinto o momento fatal - um desvario! - uma desorientação: a gula de volúpia dele salpicou-me de provocação as faces; os seios; sob minhas vestes... sob minha casta intimidade! - Oh! O turbilhão! - minha casta e recatada intimidade de virgem!...

E depois...dolorida, a gemer, senti o arfar de sua volúpia sobre meu delíquio pavoroso: sobre meu desejo quente, informe, resfolegante... um delírio!

Que estentor de lúbrica delícia inda sinto! E possuiu-me! (MAGALHÃES, 1963, p. 500)

Tudo se desmantela no Século! Tudo se irmana no mesmo caos, em destroços! (MAGALHÃES, 1963, p. 502)

O aprofundamento psicológico das personagens e o desvendamento de sua introspecção são elementos recorrentes na obra de Adelino Magalhães. Em “Chico-Vovó”, em cenas da infância de Casos e Impressões, temos a narrativa de um menino sensível que é criado com muito carinho pela sua avó, mas maltratado pela mãe por parecer um "moleirão". A vovó conta-lhe muitas histórias de príncipes e princesas. A mãe espanca-lhe quando a vovó se ausenta, pois essa não permite que o menino apanhe. Rejeitado no seio da família, o ChicoVovó compreende que ele está sozinho, pois mesmo entre os seus irmãos, o menino, sob a voz do narrador, não encontra correspondência:

Oh! Os dois nunca haviam sido verdadeiros irmãos para ele! Desde cedo, haviam-se tornado 'belos meninos' lá da Mamãe e dos amigos da mamãe; e ele, atirado ao lado, sem carícias e sem elogios, imprestável, magro e feio (ele bem o reconhecia!) fora sempre um cachorrinho, aturado na casa, apanhando as botinas e a roupa e copo de água para os outros... (MAGALHÃES, 1963, p. 152).

É evidente que sob o olhar das novas teorias pedagógicas que preferem o diálogo à surra, não compreendemos ou supomos absurdo e violento as atitudes da mãe de Chico-Vovó. Depois de ter apanhado do patrão e fugido, ao relatar o episódio para a mãe, o menino é novamente imposto à violência:

Ou antes: seu Bernardo havia dado com o metro de pau em cima dele, porque ele estava distraído no momento em que uma crioulinha entrara para comprar uns cadarços...

Ele fugiu, temendo apanhar mais; chegando em casa, àquele dia de trabalho, a Mamãe perguntou-lhe 'como era aquilo'?! Contou tudo e levou uma surra de sapato: depois, ficou preso no quarto escuro, a arroz e caldo de feijão... (MAGALHÃES, 1963, p. 152)

Um relato que também retoma a opressão no seio familiar está presente no conto "Ele e o Carlinhos", da obra Visões, cenas e perfis. Nesse texto, Zeca e Carlinhos disputam o amor da avó. O último é protegido e mais rico que os outros primos, o que já evidencia a tirania do homem contra o homem. Assim, a opressão é apresentada como uma das marcas da 
humanidade, e essa está nas relações de todos os tipos, iniciando com os pais versus os filhos, em primeira instância, após tomando outras configurações, tais como aristocracia versus proletariado, homem versus mulher, entre outros. Logo, vivemos sempre sob uma luta entre classes, pois não é desejo do homem pertencer ao universo do outro, visto que anseia pelo seu próprio mundo, aquele em que ele possa ser o centro. No conto estudado, Zeca deseja ser do mundo encantado, pois no mundo "real" não encontra espaço, tal qual o personagem de "Chico-Vovó" que também se vê oprimido. Contudo, em "Ele e o Carlinhos", somente Carlinhos é quem recebe os afagos da vovó. Vejamos os trechos abaixo selecionados:

Ele tudo fazia para contentar a Vovó, que era enfim o seu último reduto; o último agasalho que poderia esperar sua infelicidade sem remédio! Ia catar gravetos para a vovó: tentava rachar a lenha, apesar de cair extenuado nas primeiras machadadas, com grande gozo dos outros, especialmente do Carlinhos, que pegava logo no machado, como um herói vitorioso; limpava os talheres e lavava os pratos, que passavam, de novo, pelas mãos da velha Quitéria, sempre implicante, sempre a dizer:

Este menino atrapai mais do que ajuda! Arre! Que intrometido! (MAGALHÃES, 1963, p. 420)

e ele sentia que não era do mundo dos outros, mas sim de um mundo encantado: de um mundo de fadas, de estrelas (tais aquelas que já despontavam no céu), de anjos, de meninas como a Rute ou de coisas bonitas como as que ele lia nos seus poucos, mas tão belos livros!... (MAGALHÃES, 1963, p. 421)

parecia-lhe que a vida estava passando lá, à distância, e que em plena solidão, ele restava, tão abandonado!...

$[\ldots]$

E Quitéria, e os primos desatavam na mais desmoralizadora gargalhada. (MAGALHÃES, 1963, p. 422- 423)

$\mathrm{Na}$ última parte, que se denomina Casos e impressões, título da obra, Adelino apresenta-nos o monólogo interior "Francisco". Nesse texto, temos um movimento semelhante a outro conto denominado "Um prego, mais outro prego", ou seja, há um eco, uma frase, como o ritornelo da poesia, que reaparece entremeando a narrativa "Goteja! goteja!/Pam! Pam! Pam!...”. Um mendigo morre, e o narrador sente a falta desse transeunte, uma vez que esse fazia parte da paisagem da cidade, assim como as árvores, o lixo e o cão do próprio mendigo. Refletindo enquanto a chuva caía - nada mais propício -, o narrador reflete sobre a existência, sobre a fatalidade, sobre o "bulício feroz da cidade".

Percebemos no projeto estético de Adelino a tentativa, como em "Francisco", de escrever uma literatura que represente uma experiência imediata, isto é, que esteja além das intermediações simbólicas que construímos entre o mundo e nós, fundando-se na experiência adjacente que ora se mostra mais instintiva, ora mais reflexiva, como ocorre nesse texto. A representação da realidade exterior e psíquica se funde a partir do ser analisado, o mendigo: desencadeador do processo de impressões sobre a miséria humana. Essa compreensão do mundo pode ser aproximada a de Bergson, filósofo francês nascido em 1859, que dera como 
uma de suas contribuições mais importantes para a humanidade a concepção de retorno à experiência imediata, sobretudo a partir das construções e das relações que estabelecemos. Vejamos um trecho da reflexão do narrador:

Goteja! E assim, mais um prego, mais outro prego... outro fechem o vasto caixão das coisas idas, das misérias idas; daquelas que na fúria de uma pertinácia minuciosa e incansável, sob a macabra fatalidade da luta, tal qual a toada desta chuva, foram rompendo o tempo, foram se afundando no infinito... (MAGALHÃES, 1963, p. 166)

Em outro conto, "Sonho acordado de uma noite de estio", de Casos e Impressões, temos a visão de um homem em uma noite de insônia ${ }^{6}$, refletindo sobre a solidão do mundo moderno em um processo mental quase delirante, fragmentário, hermético, criando um discurso enigmático, de obscura e de aguda intelectualidade. Vejamos alguns trechos escolhidos a seguir:

Tudo corre tanto! Tudo se despedaça tanto nesta vida!

E que indiferença infinita em tudo!

$[\ldots]$

Passam, sem cessar, os automóveis!

Que voragem! A voragem da vida, sem dúvida!

Está tudo perdido!

[...]

Duas e meia!... Interessante o tique-taque do relógio!

Que caveirenta paciência... a contar assim o tempo... a contar assim o que se não acabará jamais!...

Jamais! Que abismo!...

[...]

Quantos livros, nestas minhas estantes!

Quantas filosofias, quantas ciências, quantas hipóteses e quantas verdades! Quantas sensações, quantos desvarios, quantas dores e quantas visões, dentro da policromia destas capas elegantes!

O Universo espremido nestas estantes!

E por estes livros, eu abraço a grande Ânsia humana, a Ânsia das coisas, a Ânsia Universal. (MAGALHÃES, 1963, p.183 - 184)

Nos trechos acima, entrevemos o estado de insônia e de extinção das delimitações de tempo e espaço. Além disso, as concepções apresentadas acima de desprezo ao materialismo e ao cientificismo compactuam com as idéias apresentadas pelos demais colaboradores da Revista: preferências por temas metafísicos - existencialistas e religiosos - em contraposição ao materialismo do mundo moderno. Mais do que um projeto estético, o ideário de Festa, e de Adelino Magalhães, é uma concepção de mundo.

\section{As visões, as cenas e os perfis da modernidade}

\footnotetext{
${ }^{6} \mathrm{O}$ tema da insônia também foi abordado por Graciliano Ramos no conto "Insônia", mas em Graciliano a narrativa não é fragmentada como em Adelino.
} 
No início da obra Visões, cenas e perfis, editada em 1918 e reeditada em 1932, temos uma epígrafe que nos auxilia a desvendar o conteúdo da obra: "Visões de um deslumbrado ante a feeria da vida e dos anseios humanos; psicologia dos insubmissos, desorientados em mórbidos ineditismos; cenas das sociedades onde há a sinceridade dos instintos e sofrimentos vigorosamente rudes" (MAGALHÃES, 1963, p. 187). Nessa epígrafe, o autor nos adianta que os contos terão como pano de fundo o cenário da cidade e suas diversas facetas como a velocidade, a decadência, a solidão e, com ela, o sentimento de anonimato, o materialismo e a desumanização ressurgem para delinear as marcas do mundo moderno.

Em "Lembrança à Matilde", temos o retrato de um homem mergulhado em sua sina: ficar terra a terra. Assim, em meio à plebe iletrada, um universo de corrupção e opressão sobre a classe popular é desvendado. Temos, nesse conto, a figura do escritor de cartas e, em meio ao discurso, uma frase é sempre retomada no decorrer da narrativa "Lembranças à Matilda", lembranças que não são ouvidas pelo escritor da carta e acabam não sendo inseridas ao texto. No decorrer da escritura da missiva, o narrador entrecorta o discurso das personagens e delineia um retrato de Brasil: pobre, miserável e subdesenvolvido. Vejamos nos trechos a seguir:

\footnotetext{
Geme, guitarra, em tua monotonia metálica e nostálgica!

Geme, por esses que se não sabem exprimir, que foram feitos para o trabalho e para o sofrimento humilde, ignorante, tenebroso, em terra estranha, embora esta seja o generoso Brasil!

- Mas enfim, as paredes já tremiam e o binho berde não faltou, nem as castanhas... O Chico chegou a tomar uma bebedeira que...

Geme nas mãos que te compreendem... mãos de fadiga rude; mãos grosseiras que acariciam, como uma delicadeza de aragem, as cabecinhas loiras... geme!

- Lembranças à Matilda.

Geme por eles... e diz, guitarra, a angústia desse povo condenado a uma brusca e rápida ascensão de grandeza: ao ridículo depois, entre um amigo pérfido e um filho irreverente; filho irreverente diante da irrisória decadência paterna - decadência de incultura de tristeza e de saudade" (MAGALHÃES, 1963, p. 204)
}

No conto "A greve", observamos um processo de desumanização dos homens e de humanização das máquinas que, na hierarquia social, são mais valorizadas que os proletários. Assim, em meio à organização de uma greve - que acaba não ocasionando nenhuma mudança no final do conto, e tudo volta a ser como era antes -, os eternos exploradores capitalistas, com uma ótima lábia e com o apoio da polícia, terminam com a possibilidade de qualquer negociação. Dessa forma: “A cavalaria já se havia mexido e imiscuía-se pelo grupo numa intimidade mansa, sorrateira, cheia de lábia, que ia dispersando, um tanto a custo, aquelas antiadvocatícias contra a eloqüente boquinha de dentes cariados" (MAGALHÃES, 1963, p. 230). E, em meio à multidão de operários miseráveis que lutavam pela sobrevivência, o personagem ferido pelos policiais, que se chama Aristeu, reflete em meio à imagem 
alucinante que se configura, pois percebe como se equacionam a aritmética do destino, as revoluções humanas e a trajetória do carro da História.

- Nós venceremos!...

Donde vem esse desequilíbrio... donde vem essa desigualdade?

Parecia que ansiava por responder à augusta interrogação do repórter, ali, com o braço amparado o já sonolento ferido, ao eco daquele tiroteio vizinho que quebrava vidros, que engendrava ais! no tumulto das patadas, do tilintar das espadas!

O olhar da Morte aclarava-lhe a Vida, numa grande síntese! Havia poucos meses que adoecera e que, na ociosidade pensadora da cama, numa tardinha memorável, percebera ao longe, na lonjura da sua apoucada ciência, esquecida, o grande carro triunfal da História humana, esplêndido, apoteótico de guerreiros, de fidalgos, de soberanos, de ricaços, de cantores cortesãos, de celebrados felizes... de Felizes, enfim, puxado pelo robusto e disforme Boi que, a passadas lentas, mansas e possantes, lá ia pela intérmina estrada.

E seria sempre assim...

Às vezes, para o boi irado, um engabelamento de feno melhor! gritos de humildes, macabramente anônimos, que morreram sufocados nos subterrâneos da História!

Como ele sentia uma vontade heróica de chorar!

Oh! O Povo!

O Povo! Como ele... ele era o Povo! (MAGALHÃES, 1963, p. 239)

Em outro monólogo espantoso “Avante! Avante!”, da obra Tumulto da vida, ressurge a temática da greve como elemento desencadeador das reflexões sobre as estruturas sociais, mas principalmente sobre o destino do ser humano. A concepção de que não há igualdade entre os homens, pois todos são desiguais, reitera a crítica que apresenta a cidade como o local da falta de união, da miserabilidade e do materialismo. Em meio ao confronto entre os policiais e os proletários, a rua transforma-se no local onde os homens são esmagados. O eco característico de Adelino Magalhães é configurado a partir do grito de guerra "Avante! Avante!". Observemos como se dá o tumulto em que fracos e fortes lutam numa sinfonia alucinante para aniquilar o outro em uma busca frenética pelo insondável:

$\mathrm{Na}$ rua, desta vez, foi-se aproximando, ao acaso, de um cavalariano, numa decisão louca de esbordoá-lo! Quando, de brusco, o policial vira o animal para o lado dele! Uma surpresa estrondosa tumultuou-lhe no ser: como era possível aquele soldado, que naturalmente tinha alma e tinha noiva ou filhos, voltar-se contra 'ele', que nunca lhe fizera mal?

$[\ldots]$

Fracos e fortes; pequenos e grandes, por natureza; glórias e misérias físicas, estúpidos e inteligentes, já não falando dos outros acidentes mais particulares da forma, da cor, da estrutura - a Natureza que fez os seres para viverem uns à custa dos outros, para se aniquilarem, como poderia ela admitir a igualdade, a liberdade e a fraternidade, que são os conceitos mais antagônicos ao plano geral e intrínseco de sua obra?

$[\ldots]$

Ser tão insignificante! Ter apenas a inteligência para aperceber-se dessa insignificância ante o Infinito insondável! De que valem nossas questínculas de homens, perante o universo? (MAGALHÃES, 1963, p. 360 - 361)

A cidade gloriosa e sofredora - cintilante da glória de sofrer, com o fulgor de suas injustiças e de suas desigualdades, comburidas em honra ao seu Apogeu! - a cidade, separada dele pela treva que afundava a campina num nirvânico silêncio... Assim, da treva de sua angústia, os espíritos bons, os Maiores, vêem a iluminada maldição dessa cosmópolis, que é a Vida Humana!

Cidade sofredora!... (MAGALHÃES, 1963, p. 363) 
Viva a revolução! E o sofrimento humano...

Avante! Avante! (MAGALHÃES, 1963, p. 392)

O ambiente da cidade ressurgirá em outros contos do autor como o espaço onde a apreensão, o temor e a inquietude da modernidade se alojam. A denúncia da miséria humana será tema recorrente tanto em Adelino Magalhães como em Festa. Essa agitação, promovida pela "hora veloz", é o resultado da rebeldia do grupo e do autor diante do pensamento materializado do início do século.

\section{A Inquietude da hora veloz}

A inquietude metafísica do autor vai elevando-se no decorrer de sua obra. Ainda em Visões, cenas e perfis, temos, no conto "Dias de chuva", algumas das teorias de Tranquilino, o filósofo que teria orientado Dedeco ainda em tempos de Festa, já trabalhado neste ensaio. O devaneio filosófico de Tranquilino se divide entre a influência da Bíblia e Força e Matéria, de Büchner. Assim, a partir de um dia de chuva, Tranquilino encontra-se com sua intimidade. Às vezes como um:

$\mathrm{Eu}$, um esquecido de mim mesmo e das coisas sem orientação, sem senso... Eu, para quem só tem relevo as coisas longínquas... a memória das coisas idas, que me surgem surpreendentes com o ineditismo estonteador, bárbaro, herético, excomungado, com que apareceram os mundos novos aos marinheiros dos tenebrosos mares! (MAGALHÃES, 1963, p. 266)

E, outras vezes, como aquele que percebe o contraste entre o mundo cognoscível e incognoscível, ansiando equacionar esses dois pólos que criam uma relação misteriosa dentro do filósofo, ora ele mostra-se místico e cristão, ora materialista e racional. Imersos no devaneio, não temos marcações espaciais e temporais no conto. É importante assinalar que aqui o discurso é entrecortado pelo som da chuva: o desencadeador da experiência metafísica.

Oh! Contraste entre as coisas do mundo cognoscível, contraste entre o mundo cognoscível e o mundo incognoscível!

Maldito livro da Ciência... por que sorris assim, vitorioso e mau?"

[...]

"Contraste, Pai dos seres; Pai das formas e da atividade... e resmungue eu sempre... Pai dos homens, das sensações e do gênio - contraste, Pai do Ideal, e o mais imperceptível fio, com a mais complicada estrutura contudo"

$[\ldots]$

"Adorável materialismo!

E é tudo tão profundo, e é tudo tão banal!... E pergunta-me, irônico, o adorável livro de capa amarela e velha, como um bom octogenário de triste ciência benévola da vida:

Como será Sua majestade? Venerável? Venerável, sem dúvida... amigamente venerável!"

$[\ldots]$

"Adorável espiritualismo!

E a grande... a infinita tristeza do mistério!...” (MAGALHÃES, 1963, p. 268 - 269) 
O devaneio metafísico e religioso é ainda mais intenso em "De Santa Teresa, à noite", de Visões, Cenas e Perfis, em que oração e devaneio se misturam em uma busca quase desesperada pela Hosana em meio às trombetas que soam para salvar os homens aqui perdidos:

Tão longe, porque nós não te compreendemos, Vitoriosa Luz - azul, salpicada em ânsias na derrota intensa estrondosa as trevas...

E contudo eras longamente esperada, transudação-azul, azulmente nirvânica, de todas as ânsias, de todos os ideais, de todas as sensações, de todos as misérias - de todos os anímicos séculos humanos!

E nós nos desvairamos nesta realidade, mais desvairante do que nossos sonhos!...

$[\ldots]$

A trombeta soa!

Para onde irão?

Para a glória doutros mundos?

Oh! Os mundos em que há a Dor transudando a Luz!

Trombetas soam!

Rasgam a treva heróicas ânsias... recapitulam o combate, avançando... (MAGALHÃES, 1963, p. 307 - 308)

Dominada pelos espasmos da civilização, “A Rua”, de Visões, cenas e perfis, é o lugar onde todos estão perdidos de si mesmos e dos outros. A rua ideal é o espaço da indiferença, do anonimato; é o local onde festivamente se irmana a triunfante modernização ao desespero dos homens. Tudo isso é desencadeado a partir do susto que o narrador leva ao ver um menino ser quase atropelado por essa máquina gigantesca que se chama cidade. É relevante salientar que aqui o eco de Adelino Magalhães também se apresenta a partir da reiteração, no discurso, da visão do quase atropelamento. Vejamos a seguir um trecho de como se organiza essa máquina:

Oh! Para onde irá aquele sujeito que ali passa?

Que fará ele na vida? Que função e que ideal representará?

Para onde irá?

Aquele sujeito, neste momento - uma tempestade, talvez, talvez uma aurora larga e redentora!...

A indiferença, talvez!

E essoutros, todos, que por aí passam?!... (MAGALHÃES, 1963, p. 309)

Em Tumulto da vida, nenhum conto é mais significativo da extrema fraqueza do homem e da sua miséria do que "Um prego! Mais outro prego!". Nesse texto, temos a narrativa de um doente na época em que ocorre a gripe espanhola no Rio de Janeiro, em torno de 1918, considerada uma praga mundial ao lado de outras, tais como a sífilis, a peste bubônica e a malária.

Não se sabe quantos brasileiros foram infectados e mortos pela espanhola. Nos países em que estes dados foram registrados, os números são assustadores. Na Inglaterra e País de Gales, os mortos somaram 200 mil. Na França, só entre os soldados, cerca de meio milhão contraiu a doença e 31 mil morreram. Nas tropas americanas que participaram da guerra morreram 43 mil [...] Nos Estados Unidos a gripe fez 500 mil óbitos e presume-se que, na Índia, os mortos chegaram a cinco milhões. No total, embora não se disponha de dados exatos, calcula-se que a 
doença não fez menos de 20 milhões de mortos entre 600 milhões de infectados (BERTOLLI, 1989, 32).

Logo, mesmo doente, o narrador lembra-se do som dos pregos do caixãozinho que tinha feito há pouco para a filha, pois, dessa forma, o corpo da pequena não seria misturado aos indigentes. Entrecortando o fluxo de consciência que mistura as visões do consciente e do inconsciente, já que o narrador está em estado febril, o som das marteladas ecoam: "Pam! Pam!"/ "E um prego! E mais outro prego!". Em meio ao desespero, a cidade mantém-se triunfante como que zombando dos miseráveis tomados pela epidemia.

A cidade ainda era risonha e incrédula, na despreocupada molecagem de sua agitação fátua, crente unicamente no luminoso vaivém de todos os dias! Os bondes e os automóveis e as fachadas e os homens e todas as coisas pareciam sorrir, desdenhosos a correr, a correr... superiores ao mal, vacinados contra o mal, pelo seu orgulho de Urbe intangível e privilegiada! (MAGALHÃES, 1963, p. 339).

A partir das impressões singulares de Adelino Magalhães, podemos exemplificar algumas das problemáticas apresentadas pela revista Festa. Os títulos de suas obras já direcionam à concepção do escritor, tais como: Tumulto da vida e Inquietude. Nessa última, encontramos na epígrafe a visão de modernidade como o período em que "se conturbam todos os ideais, todas as filosofias, todas as estéticas, todas as fés, num desvario clarividente de novos mundos!". E, em meio a essa miscelânea, a decadência se configura a partir da revolta, do "estardalhaço dos mal-estares", da insânia, do delírio, dos devaneios e das "convulsas cariátides a susterem o templo do Sofrimento Humano!” (MAGALHÃES, 1963, p. 335).

Em "Raiva a maldição", orar é só o que basta para aqueles que estão imersos no turbilhão e na tempestade do reino da Cosmópolis. Revoltado, o narrador contrapõe-se ao criador e ao destino traçado por este à humanidade. O discurso é entrecortado por sucessivas interjeições, o que deixa mais intensa a ira da personagem.

Soluça o Destino a fatalidade de se cumprir: soluça de querer fugir em vão à sua desgraça - o Destino que se vai, a tempestar... a tempestar...

No turbilhão, minha dor entre miríades

$[\ldots]$

É a agonia: a agonia da Civilização, que se esboroa - do Gozo são os clarins cavernentos (ouves?) - do Gozo, que escancara as fauces para o Castigo, a morrer! (MAGALHÃES, 1963, p. 494)

Nos horizontes, em longas braçadas de gozo desorgânico - o mais espiritual, o mais leve, o mais floconoso - coroado de harmonias vou... e vou... vou, e há um porto de colunatas! A tarde é um farfalhar manso de faíscas de luz, policroma! Espera-se uma embaixada da Graça de Deus. - Oremos!

$[\ldots]$

Oremos! Humanos de todas as desventuras, oremos à Alva Dona: 'Nossa Senhora, suprema expressão de Pureza e Bondade, a teus pés estamos: nós - o rancor, a perfídia, a mentira, a gula, a concupiscência! (MAGALHÃES, 1963, p. 498) 
No livro A hora veloz, o monólogo "Excelsior" também apresenta um tom de oração como resultado do desespero do homem miserável banhado por um intenso misticismo em meio à degradação que se apresenta. Esse texto é divisado por orações proféticas como, por exemplo: "Sobre o futuro, sobre a humana evolução o segredo todavia desvendar-se-á" (MAGALHÃES, 1963, p. 629). O "Excelsior" é almejado pelo narrador, imerso em profunda oração, a partir de uma linguagem fragmentada e impressionista:

Excelsior! Oh! para que duvidar?

Pelos séculos, Excelsior! Em místico, vivificante delírio!

$[\ldots]$

Há lá o reflexo esmaecido da estrada! O palor no espaço... que promessa!...

Princípio máximo... ó fulgente Abismo gerador...

Harpas de fé pela estrada; alaridos de Trovadores, liras de poetas, visões exsudando gemidos tropicais, a seguirem harpas de salmistas...

É o palor-estranho: a estrada estranha é! Aleluia!

Por onde penetrar?...

Excelsior! em místico, vivificante delírio! (MAGALHÃES, 1963, p. 630)

O compassar do relógio e, junto com ele, a desilusão dos tempos, é delineado no monólogo "Tique-taque". Nesse texto, o tema da insônia é retomado e, em meio ao fluxo fragmentado das reflexões do narrador, o discurso é entrecortado pelo eco do relógio "Tiquetaque! tique-taque! tique-taque!”. Observemos a fragmentação do fluxo de consciência abaixo como a representação da mente do homem insone:

E bate uma bigorna agora, lá, em baixo, por esta noite alta... e do meu pobre quarto, que amargura!

Há lá um gemedor som, de máquina fatigada!

Oh! tenho a idéia de que se bate a cadeia que vez mais prende a Existência ao ministério do

Sofrimento! Mais um esforço... mais esse! E essoutro...

E aqui, do meu leito, solitário no espasmo da melancolia!

Tique-taque! tique-taque!... tique-taque!...

Oh ! que tortura a minha, de pensamento : - de escutar, como uma danação, as vozes que falam, a todo instante - cortejo que não acabará mais!... santo desespero!

Quatro e dez da madrugada! (MAGALHÃES, 1963, p. 517)

Na epígrafe de Os momentos, "que fremem na exaltação dos olhos voltados para a pátria extensão, onde soluça a voz dos violões/ Os momentos que se sublimam no convulso da alma dentre de si mesma, arquejando por claridade na treva do destino. /Os momentos que se fazem gloriosa Duração!”, entrevemos, em meio ao discurso filosófico do narrador, o homem incorporado à Sensibilidade Infinita, no entanto com olhares sagazes em relação ao materialismo e ao suposto conforto oferecido ao homem: "Que mais a Civilização do que requintar as misérias naturais? Do que antepor as representações aos seres concretos, e os incidentes aos fatos primordiais - que mais consegue o Progresso?” (MAGALHÃES, 1963, p. 701). Em "Câmera", o autor satiriza um cartaz exposto em uma exposição de automóveis, brincando com a idéia de que o materialismo seria o bem para todos os males. 
Assim, não importa que o mundo esteja abafado, não interessa se você tem rancor de não ter vivido algo: “Comprem um automóvel” (MAGALHÃES, 1963, p. 717), pode ser um Cadillac, um Dodge, um Buick ou ainda um Chevrolet. O materialismo parece vencer os sentimentos mais sublimes do homem. Com os avanços da modernidade, de acordo com Adelino Magalhães, tornamo-nos cada vez mais sós e anônimos, perdidos na urbe triunfante que se apodera de nossos traços de humanidade.

Simpatizante da miséria humana, Adelino Magalhães apresenta, a partir das imagens evanescentes e fragmentadas, o refúgio no tempo interior e a crença no divino do homem em contraposição às inovações surgiam com os avanços tecnológicos. O fluxo de consciência e sua fragmentação também atestam, na forma do discurso, esse universalismo. Os contos são, em geral, uma forte crítica ao materialismo, à mecanização que separa o homem de sua realidade metafísica e de seu espiritualismo. Assim, ele sente-se incompleto, porque almeja religar-se a sua interioridade. Legatário de estéticas como o Simbolismo e o Expressionismo, o autor produz uma obra que dialoga com os preceitos de Festa de construção de uma arte universal, ou seja, a partir das sensações ou impressões, o autor abarca uma visão profunda e transcendente do ser, forma encontrada para representar o homem total vislumbrado por Tasso da Silveira e demais colaboradores do mensário.

\section{Referências}

ABÍLIO, Henrique. “A modernidade universalista da arte”, agosto de 1927, In: Festa, edição fac-similada. Rio de Janeiro: Inelivro, 1978.

. "Selvagens e fósseis", agosto de 1927, In: Festa, edição fac-similada. Rio de Janeiro: Inelivro, 1978.

. “A realidade brasileira”, dezembro de 1927, In: Festa, edição fac-similada. Rio de Janeiro: Inelivro, 1978.

“A balada tropical”, fevereiro de 1928, In: Festa, edição fac-similada. Rio de Janeiro: Inelivro, 1978.

ANDRADE, Mário. O empalhador de passarinhos. Rio de Janeiro: Livraria Martins, 1972.

- "O movimento modernista" In: Aspectos da Literatura Brasileira. São Paulo: Martins Editora, 1974.

. "Festa - nos 1, 2 e 3 - Rio de Janeiro", março de 1928, In: Festa, edição facsimilada. Rio_de Janeiro: Inelivro, 1978. 
BERTOLLI FILHO, Claudio. "A gripe espanhola em São Paulo". Ciência Hoje, vol 10, nº 56, outubro de 1989.

BRITO, Mário da Silva. História do modernismo brasileiro: antecedentes da Semana de arte moderna. Rio de Janeiro: Civilização, 1964. $2^{\text {a }}$ edição.

CACCESE, Neusa Pinsard. Festa: Contribuição para o estuda do Modernismo. São Paulo: Instituto de Estudos Brasileiros, 1971.

CAMARINHA, Mário de Sá. In: Festa, edição fac-similada. Rio de Janeiro: Inelivro, 1978. edição fac-similada. Rio de Janeiro: Inelivro, 1978.

FILHO, Barretto. "As sombras das raparigas em flor", novembro de 1927, In: Festa, edição fac-similada. Rio de Janeiro: Inelivro, 1978.

.”O espírito solitário", fevereiro de 1928, In: Festa, edição fac-similada. Rio de Janeiro: Inelivro, 1978.

. "O segundo pecado original”, maio de 1928, In: Festa, edição fac-similada. Rio de Janeiro: Inelivro, 1978.

HAUSER, Arnold. "A era do cinema" In: História social da arte e da literatura. São Paulo: Martins Fontes, 1998.

HELENA, Lúcia. “A semana de 22, ontem e hoje” In Letras de Hoje. Porto Alegre n 97, setembro de 1994.

. Modernismo brasileiro e vanguarda. São Paulo: Ática, 1986.

. "Sobre a história da semana de 22". In: MALLARD. Letícia (et al.). História da literatura: ensaios/ Campinas, SP: Editora da UNICAMP, 1994.

MAGALHÃES, Adelino. Obra Completa. Rio de Janeiro: Aguilar, 1963.

. "Já vai Dedeco para os seus quarenta", novembro de 1927, In: Festa, edição facsimilada. Rio de Janeiro: Inelivro, 1978.

. "Dedeco, discípulo amado de Tranquilino", junho de 1928, In: Festa, edição facsimilada. Rio de Janeiro: Inelivro, 1978.

MURICY, Andrade. Panorama do movimento simbolista brasileiro. São Paulo: Perspectiva, 1987; volume 2 .

"A crise da prosa", agosto de 1927. In: Festa, edição fac-similada. Rio de Janeiro: Inelivro, 1978.

. "A alma brasileira ou a falência do pitoresco", novembro de 1927, In: Festa, edição fac-similada. Rio de Janeiro: Inelivro, 1978. 
. “Alencar”, dezembro de 1927, In: Festa, edição fac-similada. Rio de Janeiro: Inelivro, 1978.

. "O dissídio com o público", janeiro de 1928, In: Festa, edição fac-similada. Rio de Janeiro: Inelivro, 1978.

. "Confiança", fevereiro de 1928, In: Festa, edição fac-similada. Rio de Janeiro: Inelivro, 1978.

. “A nova geração", maio de 1928, In: Festa, edição fac-similada. Rio de Janeiro: Inelivro, 1978.

SILVEIRA, Tasso da. Artigo de abertura, agosto de 1927 In: Festa, edição fac-similada. Rio de Janeiro: Inelivro, 1978.

. "A modernidade universalista da arte", agosto de 1927, In: Festa, edição facsimilada. Rio de Janeiro: Inelivro, 1978.

. "Renovação", novembro de 1927, In: Festa, edição fac-similada. Rio de Janeiro: Inelivro, 1978.

. "O simbolismo brasileiro", dezembro de 1927, In: Festa, edição fac-similada. Rio de Janeiro: Inelivro, 1978.

- "A árvore", dezembro de 1927, In: Festa, edição fac-similada. Rio de Janeiro: Inelivro, 1978.

. "A enxurrada", janeiro de 1928, In: Festa, edição fac-similada. Rio de Janeiro: Inelivro, 1978.

- "Alegria criadora", fevereiro de 1928, In: Festa, edição fac-similada. Rio de Janeiro: Inelivro, 1978.

. "Totalismo criador", março de 1928, In: Festa, edição fac-similada. Rio de Janeiro: Inelivro, 1978.

. "Queremos ser ou o nacionalismo brasileiro", maio de 1928, In: Festa, edição facsimilada. Rio de Janeiro: Inelivro, 1978.

. "Cateretê n 5 para sanfona e violão", junho de 1928, In: Festa, edição fac-similada. Rio de Janeiro: Inelivro, 1978.

. "Três simples sugestões sobre a arte brasileira (romance, poesia, teatro)", julho de 1928, In: Festa, edição fac-similada. Rio de Janeiro: Inelivro, 1978.

. “A descoberta da alegria", agosto de 1928, In: Festa, edição fac-similada. Rio de Janeiro: Inelivro, 1978.

"Instinto de tatu ou desiludidos de si mesmo", setembro de 1928, In: Festa, edição fac-similada. Rio de Janeiro: Inelivro, 1978. 
"Batuque p'ra começar", janeiro de 1929, In: Festa, edição fac-similada. Rio de Janeiro: Inelivro, 1978.

TELES, Gilberto Mendonça. Vanguarda européia e modernismo brasileiro. Rio de Janeiro: Vozes, 1978. 